\title{
Infantile basal ganglia stroke after mild head trauma
}
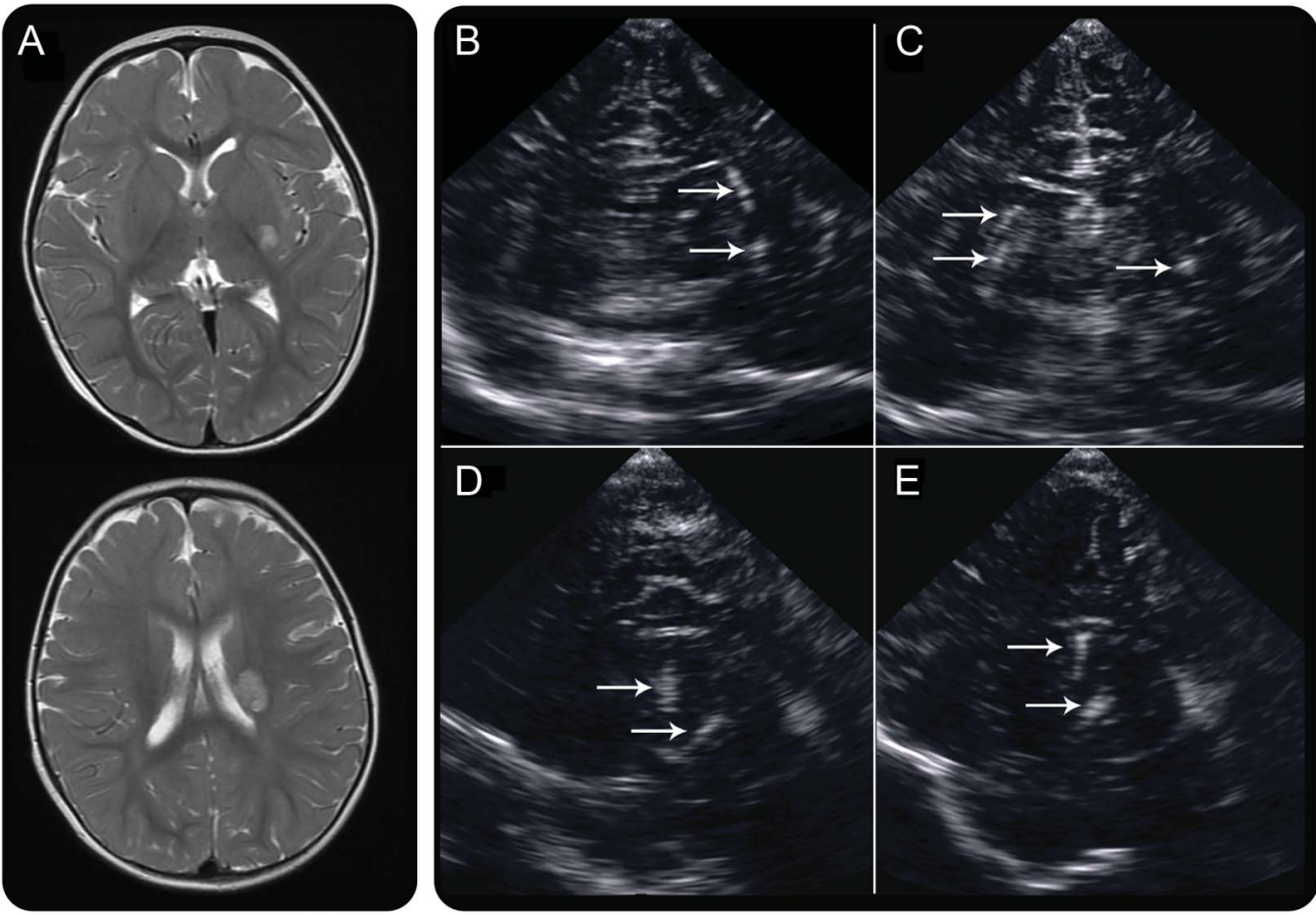

MRIs showed a left posterior putamen ischemic lesion extending to the internal capsule (A). A cerebral ultrasound examination identified lenticulostriate vasculopathies, which are not shown by MRIs. Bilateral multiple lenticulostriate vasculopathies were observed in coronal (B, C), and left (D) and right (E) parasagittal views (arrows).

A 13-month-old boy presented to our hospital with a history of right hemiparesis and right facial paresis for 2 days. These symptoms occurred several hours after a fall from a bed to the ground. An MRI of the brain showed an ischemic lesion and cerebral ultrasound examinations demonstrated bilaterally hyperechogenic lenticulostriate arteries (figure).

Infantile basal ganglia stroke after mild head trauma is a rare condition in childhood. ${ }^{1,2}$ Lenticulostriate artery mineralization, lenticulostriate vasculopathy, is implicated as the pathologic substrate in this type of stroke. ${ }^{1,2}$ Rigid mineralized arteries increase the vulnerability of the vessels to shear injury during mild head trauma. ${ }^{1,2}$

\section{Su-Tin Yang, MD, Wang-Tso Lee, MD, PhD, Kun-Long Hung, MD, Chaw-Liang Chang, MD}

From the Department of Pediatrics (S.-T.Y., C.-L.C.) and Center for Medical Teaching and Research (C.-L.C.), Cathay General Hospital, Hsinchu; Department of Pediatrics (W.-T.L.), National Taiwan University Hospital, Taipei; and the Department of Pediatrics (K.-L.H.), Cathay General Hospital, Taipei, and School of Medicine, Fu-Jen Catholic University (K.-L.H.), New Taipei City, Taiwan.

Author contributions: Su-Tin Yang: patient management and drafting the manuscript. Wang-Tso Lee: patient management, revising the manuscript for content, and final approval of the manuscript. Kun-Long Hung: study supervision, revising the manuscript for content, and final approval of the manuscript. Chaw-Liang Chang: study concept, acquisition of data, analysis and interpretation, and final approval of the manuscript.

Study funding: No targeted funding reported.

Disclosure: The authors report no disclosures relevant to the manuscript. Go to Neurology.org for full disclosures.

Correspondence to Dr. Chang: juliancsr@yahoo.com.tw 
1. Lingappa L, Varma RD, Siddaiahgari S, Konanki R. Mineralizing angiopathy with infantile basal ganglia stroke after minor trauma. Dev Med Child Neurol 2014;56:78-84.

2. Yang FH, Wang H, Zhang JM, Liang HY. Clinical features and risk factors of cerebral infarction after mild head trauma under 18 months of age. Pediatr Neurol 2013;48:220-226.

\section{Get Connected. Stay Connected.}

Connect with the American Academy of Neurology's popular social media channels to stay up-todate on the latest news and breakthroughs in neurology, and network with peers and neurology thought leaders. Visit $A A N . c o m / C o n n e c t$.

\section{Pit Neurology.org Offers Important Information to Patients and Their Families}

The Neurology ${ }^{\circledR}$ Patient Page provides:

- A critical review of ground-breaking discoveries in neurologic research that are written especially for patients and their families

- Up-to-date patient information about many neurologic diseases

- Links to additional information resources for neurologic patients

All Neurology Patient Page articles can be easily downloaded and printed, and may be reproduced to distribute for educational purposes. Click on the 'Patients' link on the home page (Neurology.org) for a complete index of Patient Pages.

\section{Introducing Stackly}

Organize. Disseminate. Collaborate. Discover.

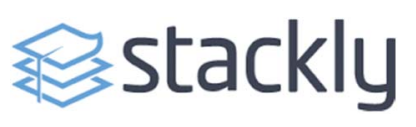

With simple tools for collecting, organizing, and sharing research materials, Stackly is the new center of your research world.

- Share what you find and discover what others share

- Collaborate with colleagues on topics that matter to you most

Stackly will integrate with your web browser and work directly with all Neurology ${ }^{\circledR}$ Journals as well as other publication sites. Access Stackly on the home page and to the right of each article. Visit http://www.neurology.org/site/includefiles/homepage/stackly.xhtml to learn more and start stacking for FREE. 


\section{Neurology}

\section{Infantile basal ganglia stroke after mild head trauma \\ Su-Tin Yang, Wang-Tso Lee, Kun-Long Hung, et al.}

Neurology 2015;84;2381-2382

DOI 10.1212/WNL.0000000000001669

\section{This information is current as of June 8, 2015}

\section{Updated Information \& Services}

\section{References}

Subspecialty Collections

Permissions \& Licensing

\section{Reprints}

including high resolution figures, can be found at: http://n.neurology.org/content/84/23/2381.full

This article cites 2 articles, 0 of which you can access for free at: http://n.neurology.org/content/84/23/2381.full\#ref-list-1

This article, along with others on similar topics, appears in the following collection(s):

Brain trauma

http://n.neurology.org/cgi/collection/brain_trauma

Childhood stroke

http://n.neurology.org/cgi/collection/childhood_stroke

Pediatric stroke; see Cerebrovascular Disease/ Childhood stroke $\mathrm{http} / / /$ n.neurology.org/cgi/collection/pediatric_stroke_see_cerebrovascu lar_disease-childhood_stroke

\section{Ultrasound}

http://n.neurology.org/cgi/collection/ultrasound

Information about reproducing this article in parts (figures,tables) or in its entirety can be found online at:

http://www.neurology.org/about/about_the_journal\#permissions

Information about ordering reprints can be found online:

http://n.neurology.org/subscribers/advertise

Neurology ${ }^{\circledR}$ is the official journal of the American Academy of Neurology. Published continuously since 1951, it is now a weekly with 48 issues per year. Copyright () 2015 American Academy of Neurology. All rights reserved. Print ISSN: 0028-3878. Online ISSN: 1526-632X.

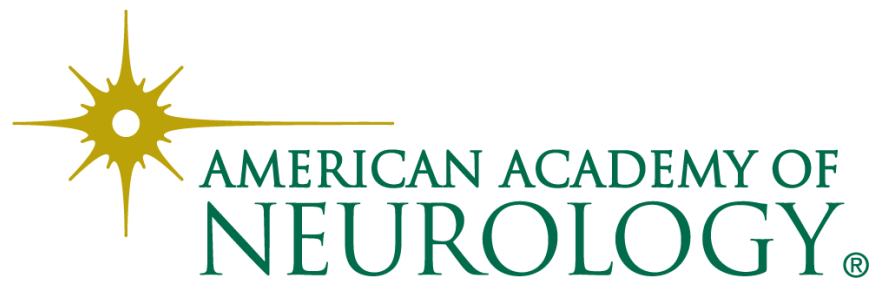

